\title{
DESTINY OF INJUSTICE IN WILLIAM LANDAY'S NOVEL DEFENDING JACOB
}

\author{
Sudwintari, Sri Wulan \\ English Department, Faculty of Literature, \\ Universitas Islam Sumatera Utara, Medan, Indonesia \\ e-mail: sudwintari03@gmail.com
}

\begin{abstract}
This study discusses Protagonist's Destiny of Injustice in William Landay's novel Defending Jacob. This study adopts much of Gulen's theory about destiny and injustice which is quoted by Haderi. Then, this research is completed by adopting descriptive qualitative method. There are three forms of the protagonist's destiny of injustice. They are being accused of murder, being dismissed from school, and being isolated. The findings of the analysis are the protagonist has got many things for his injustice. The protagonist really suffers the injustice. The protagonist has passed several trials to be declared not guilty and free. It can be found clearly that the protagonist in this novel meets his destiny of injustice. At last, fortunately the protagonist is free from the accusation because the murderer has been revealed. The ending of the story shows that the protagonist can be free from the accusation because actually the one who kills his classmate is a pedophile.
\end{abstract}

Keywords: protagonist, destiny, injustice, accusation, pedophile

\section{Introduction}

The essence of literary work is the work has a specific mission that concerns the issues of life and human life (Ismail, 2011). Likewise, novel tells life that happens in society such as social problems, one of which includes the problem that is crime or criminality. Literary works cannot be separated from the author. Through his literary work, the author wants to convey something to other people about the specific problems that occur in life. Here, it is the advantages of artists or authors with other human beings, because artists or authors can express their imagination in a work, in the form of literature, as well as novel.

This novel is a work that tells about story of assistant district attorney in the state of Massachusetts in the United States for more than two decades, the man is named Andrew Barber or better known as Andy barber. He is respected, admired in the courtroom. He lives happily with his wife Laurie, and also with their teenage son, Jacob Barber. Jacob attended the McCormick school. Then a murder event happened in the Cold Spring Park, near their home. The life of Andy's family has changed, because Jacob is accused of stabbing his classmate to death, his named is Ben Rifkin. Ben Rifkin's stab happened in the cold spring park. This case has also passed six trials. As a father, instinct to defend his son to prove that Jacob is not guilty of the case continues to blaze within Andy. He makes various ways to defend Jacob, from the injustice of his son's destiny. Because he believes that his son is not guilty and free from the accusation. 
Two life portrays that may be common to find in a novel are destiny and injustice. Destiny determines everything, or explains the level of something. The meaning of destiny can also be interpreted by assessing something for a certain judgment, such as estimating the strength of an object, its level or value. According to theology, destiny in general is related to human personal actions that lead to the part of human in acting and doing, and raises all roles and strengths for all their actions (Gullen, 2015).

Destiny, which is told in William landay's novel Defending Jacob, refers to the injustice that is used as the idea underlying the novel's story. Defending Jacob always presents the process of injustices related to the actions try to restore a teenager's good reputation who have been polluted. Based on this, a novel can be used as a tool to convey the feelings and contents of the author's heart. To find out this, we need to examine the novel.

The author composes this novel which contains the story of the accusations of murder that is alleged to Jacob, a teenagers son, because the struggle for legal proceedings is very long in order to be free from injustice on the charge of murder with collect supporting evidence. The author wants to share his inspiration story to his readers to be more persistent in trying to get justice for the injustice experience, and be careful about behave, and also speech in interacting in the social environment to avoid misunderstanding that can adversely affect life sustainability in the future.

Many injustices contained in the Defending Jacob can provide motivation for the readers. When some people who experience the same thing begin to despair due to the injustice of their destiny, Defending Jacob states that there is no justice that can be achieved easily or instantly. All must go with hard efforts to escape the injustice of the destiny that occurred. Based on the background of the problem above, it is to examine more deeply the protagonist's destiny of injustice in William Landay's novel Defending Jacob.

\section{Literature Review}

\subsection{Destiny}

Bryan (1989) says that destiny is not a matter of chance; it is a matter of choice. It is not a thing to be waited for, it is a thing to be achieved. To support the above is idea, Schielke, HAU (2018): Jurnal Teori Etnografi defines that destiny describes us to accept that the course of important events is decided independently of what we want or choose. It also describes us that we need to act to make it happen, to inhabit that which will happen, and perhaps to manipulate or change it to our advantage. He also said that destiny is also a relationship humans have with each other. Destiny is not always on the side of established hierarchies, and sometimes socialist revolutionaries find God on their side (Schielke 2015: 222-23). But destiny teaches us that free choice and individual autonomy are fictions useful, inspirational fictions perhaps, but fictions all the same. Destiny, also, more often than not, describes us that this is how it should be, that those who have power are destined to have it. Destiny provides helpful allies or generous masters. As a moral relationship of power, destiny turns chance encounters into divine gifts, and times of hardship into second chances. Equally, it also turns privilege into entitlement, and force into legitimate authority.

Gülen in Haderi (2014) said that destiny is everything that exists, from subatomic particles to the universe as a whole. Gülen analogizes destiny as follows: Authors have full and exact knowledge of the books they will write, and arrange its 
contents before writing it. In this sense, Destiny is almost identical with Divine Knowledge, or is a title of Divine Knowledge. It is therefore also called the Supreme Preserved Tablet (or the Manifest Record). Destiny also means that God makes everything according to a certain, particular measure and in exact balance: God knows what every female bears and what the wombs absorb and what they grow. And everything with Him is measured. The sun and the moon are made punctual according to a calculation. The stars and the trees adore, in subservience to Him. And the sky He has uplifted; and He has set the balance, that you exceed not the balance, but observe the balance strictly, nor fall short there of. Thus, believing in destiny is one of the important beliefs. If the question arises: why is destiny one of the important beliefs? Fethullah Gülen gives the answer as follows: "Our self-pride and weak obedience cause us to offer our expertise and good deeds to ourselves and feel proud of ourselves. Gülen added, which is included in that destiny is capacity, strength, and adequate equipment to get many things, which causes us to be able to realize various skills and good deeds.

Haderi (2014) also says that an interesting thing about Fethullah Gülen's destiny is that we can attribute what has happened as destiny in order to get a solution. This thinking is based on the nature of humans who usually complain about the events of injustice and suffering in the past. Even worse, we sometimes despair and abandon ourselves in a cruel lifestyle, and even begin to complain to God. This is why, according to Fethullah Gülen, destiny allows us to connect the events of injustice and suffering in the past with these complaints so that we can get relief, security, and solace.

\subsection{Injustice}

Injustice is a quality relating to unfairness or undeserved outcomes. The term may be applied in reference to a particular event or situation, or to a larger status quo. In Western philosophy and jurisprudence, injustice is very commonly the sense of injustice is a universal human feature. Though the exact circumstances considered unjust can vary from culture to culture. While even acts of nature can sometimes arouse the sense of injustice, the sense is usually felt in relation to human action such as misuse, abuse, neglect, or malfeasance that is uncorrected or else sanctioned by a legal system or fellow human beings.

The sense of injustice can be a powerful motivational condition, causing people to take action not just to defend themselves but also others who they perceive to be unfairly treated (Wikipedia, 2019).

Shklar (1992) wrote in his book with the etitled "The Faces of Injustice" said that historical writing and fiction use instances of injustice as subject matter far more often than justice. In philosophy and jurisprudence, the dominant view has been that injustice and justice are two sides of the same coin - that injustice is simply a lack of justice.

Injustice according to Hayek (1978), the earliest known thinker states that injustice is the primary quality was Heraclitus, whose view was echoed by Aristotle and dozens of others down the centuries. Hayek said that "writers often express the idea that injustice is the primary concept "as though it were a new discovery", suggesting the view is rarely directly expressed in theories on Justice. But Hayek went on to say that legal positivism has proved that injustice, not justice, is the primary quality.

Weil (1995), Wolgast (1987) hold that the sense of injustice is a powerful motivational condition - unlike the sense of justice which tends to be conceived in more abstract ways, and tends to inspire contemplation rather than action. 
King Jr (1963) puts it injustice anywhere is a threat to justice everywhere. Moore (1978) says that a widely shared sense of injustice is an essential, though not sufficient, cause of rebellion. Writers including Weil, Wolgast and Shklar have said that an aroused sense of injustice can be an essential prerequisite to action needed for protecting the weak and afflicted.

A common cause of injustice is human selfishness. As Plato describes at length in The Republic, "people will often commit acts of injustice when they calculate it is in their interests to do so". Plato also adds that "The highest reach of injustice is to be deemed just when you are not" (Wikipedia, 2019).

Injustice is an act by social institutions or individuals who take sides with one or both parties to the dispute. Injustice cannot be separated from destiny because according to Haderi (2014) Gülen's destiny is that we can attribute what has happened as destiny in order to get a solution. This thinking is based on the nature of humans who usually complain about the events of injustice and suffering in the past. Based on the above understanding, destiny needs hard effort in its implementation committing with destiny will create someone be a strong person in facing injustice. Destiny and injustice are a combination of an absolute whole.

\section{Research Method}

This study applies qualitative research with narrative approach. According to (Creswell, 2013: 72), narrative researchers collect stories, documents, and group conversations about the lived and told experiences of one or two individuals. They record the stories using interview, observation, documents and images and then report the experiences and chronologically order the meaning of those experiences. In addition, this study was also analyzed using a sociological approach to literature. In the approach of literary sociology, literary works are seen from their relationship with reality, the extent to which literary works reflect reality, and in line with this, Hidayati (2019) states that the reality is quite broad in meaning, that is, everything that is outside the literary work and which is referred to by the literary work itself.

\section{Discussion}

\subsection{Being Accused of Murder}

The protagonist, Jacob Barber is a fourteen-year-old boy that being accused of murder his classmate named Ben Rifkin. The following quotation shows the condition:

Derek Yoo (McCormick Middle School) wrote at 2:25 pm on April 15th 2007. Jake, everyone knows you did it. You have a knife. I've seen it. (Landay, 2012: 59)

Andy Barber, Jacob's father, get the post from an email message from Jacob's friend, Sarah Groehl. The message directs him to a Facebook group link named @ friends of Ben Rifkin. It is where the situation of injustice from the case is experienced by Jacob. The following quotation shows how the accusation led to Jacob:

In the top drawer of the Bureau, I found something hard, lazily hidden in an old White T-shirt. I unrolled the T-shirt until it spilled onto the bureau a folding knife with a black rubberized Handle.

It might have been a military knife or a hunting knife, but then it seemed to small for that. Unfolded, it was about ten inches long. The handle was 
black, grippy, shaped to accept four fingers. The blade was hook-Shaped, with an intricately serrated cutting edge-a ripping blade-and it came to a lethal gothic point. The flat sides of the blade had been drilled out, presumably to save weight. The knife was sinister and beautiful. (Landay, 2012: 60)

Half the state police is looking for a knife of the same type as the knife that Jacob has. Because the killer who killed Ben uses the type of knife based on the evidence of the wound on the victim. The reason Jacob buy the knife is because it looks so cool that he wants to have it. Once, Jacob brings the knife to school to show it to some of his classmates including Derek Yoo, who makes him accused of being the killer who spread Ben through their Facebook group. Jacob's father tries to avoid the accusation which would have cause injustice to Jacob by removing the knife, as quoted in the following:

"No, I just wanted that knife out of my house. And I didn't want anyone using it to make Jacob look guilty when he's not. That's all". (Landay, 2012: 85)

But injustice cannot be avoided at that time. Paul Duffy, representing the police delivers bad news to Jacob's parents, here the quotation about that:

"Andy, just so you know, we found a knife this morning in the park. It was in the muck next to a lake" (Landay, 2012: 99).

The above quotation shows that the knife is used as the main reason for setting Jacob as a suspect. At the next trial, Jonathan as a lawyer defend Jacob laid out the essentials of the police reports and government's evidence. It is seen in the following quotation:

"The theory, "he said, "seems to be that Ben Rifkin was bullying you, therefore you got a knife and, when the opportunity presented itself or perhaps when the victim bullied you one time too many, you took your revenge. There don't seem to be any direct witnesses. A woman who was walking in Cold Spring Park places you in the area that morning. Another walker in the park heard the victim cry out, 'stop you're hurting me,' but she didn't actually see anything. And a fellow student-that's Logiudice's phrase, a fellow student-alleges you had a knife. That fellow student is not named in the reports I have here. Jacob, any idea who that is?"

"It's Derek. Derek Yoo."

"Why do you say that?"

"He said the same thing on Facebook. He's been saying it for a while." (Landay, 2012: 127)

When in Jonathan's attorney's office, Jacob and Jacob's father begin a discussion about the reason why Jacob once has the same type of knife that is used to kill Ben and it becomes the factor in the injustice of Jacob as a murder suspect, and the reason why his father throws away the knife from his house before Jacob is set, allegedly the person who has killed Ben. It is emphasized with the following quotation:

Jonathan : "Tell me about the knife." 
Jacob : "What do you want to know?"

"Well, the DA is going to say you bought it because you were being bullied. They'll say that's your motive. But your told your folks you bought it for no reason."

"I didn't say I bought it for no reason. I said I bought it because I wanted it." (Landay, 2012: 159)

"Jacob, the knife is gone?"

"Yeah. My dad took it."

"You have the knife, Andy?"

"No, it's gone."

"You got rid of it?"

"It was dangerous. It wasn't an appropriate knife for a kid to have. It wasn't a toy. Any father would have"

(Landay, 2012: 159-160)

The situation is held when they are sitting at the round oak table in his office, the only room Jonathan has that is large enough to accommodate our entire family. The next day, Jacob's father meets Sarah, one of Jacob's friends and Ben's friend at school. Sarah says that during his life, Ben always abuses Jacob in school. The quotation that support the explanation above:

You know, there were these rumors going around and I thought you should know what kids were saying. 'cause nobody seemed to know, you know? Like, nobody who was in charge. No offense, but you all seemed kind of clueless. Kids knew. Kids were saying Jacob had a knife, and Jake and Ben had a fight. You guys were running around totally clueless. Actually Ben had been kind of bully to Jake for a long time, you know? It wasn't like that makes anymore a murderer, all right? But it was just kind of something I thought you guys should know. (Landay, 2012: 169)

The reason of the abuse of Jacob is because Jacob is not exactly in the cool crowd. He is just an ordinary person. He seems to be utterly friendless; this is what causes Jacob finds friends through social media. Moreover, the same kids who are willing to link to Jacob online refuse to acknowledge him in person. Before Ben's murder case exists, the number of friends on Jacob's Facebook account is more than those in the new account owned by Jacob named Maevin Glasscock in his new account. Jacob makes a mistake that further worsene Jacob's destiny. It can be proven in the following quotation:

It finally came in mid-august. Early on a Sunday morning I glanced at Marvin Glasscock's Facebook page to find an image of Anthony Perkins in Psycho, the famous silhouetted figure with a knife raised over his shoulder to stab Janet Leigh in the shower, now with Jacob's face photoshopped onto it-Jacob as Norman Bates. The face was clipped from a snapshot of Jacob, apparently at a party. It showed Jacob grinning. Jacob had posted the mash-up photo with the caption "What people think of me." His friends responded with these comments: "Dude looks like a lady." "Awesome job. You should make this your new profile pic." 
"Wee-wee-wee [psycho music]." "Marvin Glasscock! Dude comes in with the total facemelter !!!"(Landay, 2012: 188-189)

Every online move creats a record. Every keyboard click is recorded and stored on a server somewhere. Nothing they do on the Web-nothing-is private. And unlike a phone call, this is a written form of communication: they are generating a transcript of every conversation. The Web is a prosecutor's fantasy, a monitoring and recording device that hears lurid secrets, even those never spoken out loud. It is better than a wire. It is a wire planted inside everyone's head. Jacob's father does not immediately delete the photo, but he asks the intention of Jacob to post the picture and the caption on his new Facebook account, and Jacob's response is only a joke. Jacobs's father give an explanation to Jacob if the joke can be an opportunity for Jacob to feel the destiny of living in prison for a long time, as described in the following quotation:

"Jacob, do you know what they're going to do whit this pictures? They're going to wave it around in front of the jury and do you know what they're going to say? They're going to say it shows consciousness of guilt. that's just the phrase they'll use, consciousness of guilt. They'll say, 'This is how Jacob Barber sees himself. Psycho. When he looks in the mirror, this is the reflection he sees: Norman Bates. 'they'll use the word psycho over and over, and they'll hold this picture up and the jury will stare at it. They'll stare at it and guess what? They'll never be able to forget it. (Landay, 2012: 190)

Jacob's father argues that It does not make any sense because Jaxob still insists that what Jacob means in his account is just a joke and the story is not about Jacob. here, Jacob is just being smart, and ironic. But the Prosecutors and jury will consider it an implied confession Jacob has done. As a result, even though the image and caption Jacob has posted on his new Facebook account named Marvin Glasscock has been removed, it has become additional evidence to make it difficult for Jacob to escape the destiny of injustice being accused of murder, as verified bellow:

'No! we can't just delete it. That's the whole point! It doesn't go away, Jacob. we can delete it but it doesn't go away. When your buddy Derek goes to the DA and tells him you have a Facebook account named Melvin Glasscock or whatever and you put this picture up, all the DA has to do is send them a subpoena and he gets it. Facebook will just give it to him, all of it. This stuff sticks to you. It's like napalm. You can't do this. You can't do it”. (Landay, 2012: 191)

Jacob apologizes to his father but the word sorry cannot change the situation that is getting worse than before. so that this evidence does not burden Jacob at the next trial, Jacob's father looks for other evidence that can alleviate Jacob's case in the next court where one day he meets one of Jacob's friends who now does not want to be friends with Jacob anymore. The person is named Derek Yoo. Derek tells that Ben is a cruel person, Ben always abuses Jacob every time he meets at school, as indicated in the following quotation:

There was just something about Jake that Ben didn't like, and that kind of got him excited, you know? It was like he couldn't help himself. If he saw Jake, he gave him a rash. Every time. I guess he figured he could get 
away with it too. To be honest? Nobody likes to say it because he got killed and everything? But Ben was a mean kid. Who ever did this- well, I don't know, I don't want to say-whatever. Ben was just a mean kid".(Landay, 2012: 205)

The suggestion that murder is the family business comes awfully close to the argument Logiudice has been barred from making. But Jonathan Jacob's lawyer, does not object. He cannot appear to be obstructing the prosecution with technical, legalistic the fenses, his defense will not be technical: Jacob does not do it. Jonathan does not want to muddy that message.

\subsection{Being Dismissed From School}

By setting Jacob as the perpetrator who kills Ben, Jacob must prepare himself to accept the destiny of being a homeschooling student. Because the school decides that Jacob should be dismissed for all of his school activities. Within an indefinite time limit, as shown bellow:

He was now utterly alone. No one over called him or visited. He had been suspended from school and, come September, the town would be obliged to hire a tutor for him. The law required it. Laurie had been negotiating with the school department for weeks, haggling over how much in-home tutoring Jake was entitled to. (Landay, 2012: 188)

The above quotation shows that the school does not want the school to get a bad image by letting someone suspected of committing a crime continue to attend school. Doing injustice by dismissing Jacob is the best solution to maintain a good image of the school.

\subsection{Being Isolated}

The injustice caused by the murder accusation directed to Jacob not only affects Jacob's life but also on Jacob's father, Andy Barber. Andy is previously an assistant district attorney in Massachusetts and also handles Ben Rifkin's murder case. But after it is discovered that his son is involved in the case, Andy is not allowed to handle the case again and the case is taken over by Neal Logiudice. Andy is also suspended from his job as an assistant district attorney. The following quotation shows the injustice:

"We're putting you on paid leave. It's partly my fault: it was a mistake to let you have the case in the first place. These guys" she gestured toward the troopers "will go to your office with you. You can take your personal belongings. No papers, no files, you are not to touch the computer. Your work product belongs to the office". (Landay, 2012: 93)

Not enough to get there, the next injustice that occurres is Andy is banned from coming to the temporary courthouse. It is gotten in the following quotation:

"Andy", the district attorney advised, waving away my pleading like smoke, "It'd probably be best for everyone if you stayed away from the courthouse for a while. let the dust settle. Okay?" (Landay, 2012: 94)

In his office, he tosses a few things into a cardboard box. All the years, the works, the friendships, the respect he has accumulated by little spoonfuls in case after 
case. All go now, no matter how Jacob's case turn out. For even if Jacob's is cleared, Andy will never escape the stain of the accusation. The stink will never leave him. He doubts he will never walk into a courtroom again as a lawyer. But thing is racing to fast to linger over the past or future. There is only now. Jacob and his parents also have to accept the destiny of getting a bad image from various media, because at that time the case has become public consumption, as revealed $n$ the following quotation:

That morning the Globe had run a page-one headline: DA's Teen SoN CHARGED IN NEWTON KILLING. The Herald was sensational but, to its credit, Forthright. Its tabloid cover showed a background photo of what appeared to be the murder scene, an empty slope in a forest, with a snapshot of Jacob that they must have culled from the Web, and the word MONSTER. There was a teaser at the bottom: "prosecutor benched amid allegations of cover-up as his own teenage son is unmasked in Newton knife murder".(Landay, 2012: 113)

Must be remembered, in public's eyes, in everybody's eyes, Jacob is guilty. His parents are guilty. Public only want something to confirm what they already know. Any little scrap will do. On the other hand, the following quotation expresses the coworkers from Jacob's father also begin to believe that Jacob has been named the murderer:

The crowds of lawyers, most of whom I knew well, stood back as if there were a magnetic field around us (Landay, 2012: 114).

The situation of the above quotation happens when Jacob and his parents arrive at the courtroom around a quarter of an hour earlier before the trial is started. And the trial that day ended with Jacob being declared a city prisoner by paying bail first. While outside the court building, so many reporters are ready to wait for, and record the destiny of Jacob's injustice through the lens of their camera in all ways to fulfill the public's curiosity over the case. This quotation has found the condition:

The bail was arranged quickly, and Jacob was released to us. Together we left the courthouse through a gauntlet of reporters that seemed to have grown since we arrived. Grown more aggressive too: out on Thorndike street, they tired to stop us by standing in our path. Somebody-it may have been a reporter, though no one saw him-pushed Jacob in the chest, knocking him back a few steps, trying to elicit a response. Jacob gave none. His blank face never wavered. Even the more polite ones had a slippery tactic to get us to stop and talk: they asked, "can you just tell us what happened in there?" as if they did not know, as if the whole thing had not been broadcast to them via the live video feed and text messages from their colleagues. (Landay, 2012: 119)

The above quotation shows that this case has become a hot topic from various circles at that time in Massachusetts. One of the consequences of the widespread spread of this case in various media is that Jacob and his parents are terrorized by someone unknown. They are terrorized by the time Jacob and his parents round the corner and drove up to their home after returning from the Jacob's trial. as Jacob's father begin to turn the car into the driveway, they see the writing on the wall of their house.

There was graffiti on the front of our house, drawn with a thick black marker. 


\section{MURDERER \\ WE HATE YOU ROT IN HELL}

The letters were big, blocky, and neat, written in no particular haste. Our house was faced with tan shingles, and the edges of these shingles caused the pen to skip as it crossed from one to the next. Otherwise it had been done carefully, in broad daylight, while we were gone. The graffiti had not been there when we left that morning, I am sure of that. (Landay, 2012: 120)

Someone walks right up and write on their house and nobody says anything, nobody lifts a finger, not one of their neighbors. The attitude of the neighbors towards Jacob and his parents increasingly show injustice with they do not want to communicate directly or indirectly to the murderer's family accused to Jacob and his parents. The quotation that support this is seen as the following:

I was determined to keep on doing it even after Jacob was indicted. No doubt, the neighbors would have preferred that we Barbers not show our face, particularly in Cold Spring Park. I did accommodate them somewhat. I ran early in the morning, i kept my distance from others, I bowed my head like a fugitive when passing a jogger going the opposite direction. And of course I never ran near the murder site. But I decided from the start that, for my own sanity. I would hold on to this aspect of before-life (Landay, 2012: 135)

Most mornings around six or six-thirty Jacob's father galumph through the streets and the jogging paths in Cold Spring Park until he has pounded out his daily three miles. The same attitude is done by Jacob's friends, his friends have all dropped him cold. While on the other hand, Jacob feels that injustice begin to isolate his rights as a social person to argue and interact through social media. Facebook freeze Jacob's account, probably because of a subpoena compelling the production of everything he has ever posted. But with social persistence. The following quotation proves an evidence that he opens a new Facebook account under the name Marvin Glasscock and begins friending his inner circle again with a number of rules made by his parents:

Jacob was completely isolated now and his "online life" was such a necessary, integral, "natural" part of how kids socialize that it would be cruel to deny him even this minimal human contact. i reminded her that the commonwealth of Massachusetts intended to deprive him of a hell of a lot more than that, and we agreed at least to place some limits on the new account. Jacob was not to changed the password, which would deny us access and the ability to edit him; he was not to post anything that touched on the case even remotely; and he was strictly forbidden to post photos or video, which were impossible to keep from squirting around the internet once they got loose and which could easily be misconstrued. (Landay, 2012: 187)

Jacob's father makes a part of his morning rounds on the internet to check what Marvin Glasscock which is Jacob has written on Facebok the night before. Then, if, all is clear, Jacob's father will disappear down of the internet for a few minutes to forget 
the raging storm he is standing in. On the other hand, Jacob and Jacob's parents begin limiting their activities in public area, such as going to a shop near their house to shopping for their daily needs. It is all done so that Jacob and Jacob's parents are not allowed to have fun on Ben's death by public. It is related in the following quotation:

There was another reason for us to avoid Whole Foods as well. I was determined not to be seen around town, certainly not to do anything that might suggest we were taking the case lightly. It was a question of image. I wanted people to see our family as shattered, because we were shattered. When the jury pool filed into the courtroom, I did not want any of them to harbor some vague memory of the Barbers luxuriating in pricey shops while the Rifkin boy lay buried in the ground. An unflattering mention in the newspaper, a fanciful rumor, a baseless impression-these things could easily tip the jury against us. (Landay, 2012: 214)

This condition of the destiny of injustice shows that how difficult the day after day that Jacob must go through and face. Jacob must also accept a harsh reality that his social life is isolated because his bad image as a murderer causes public do not want to socialize with him and also with his parents. Even until a fact is finally discovered, Jacob is not the real perpetrator, public also will not want to socialize with him and his parents.

\section{Conclusion}

Analyzing the variable of this study and finding the result, it can be concluded that there are three forms of the protagonist's destiny of injustice which are found in this novel. Besides, from this study it can be seen an enlightenment that human life cannot be separated from injustice and destiny because sometimes people find a big matter in their state of injustice. So, they have to change the destiny to solve it.

Indeed, in this world, not a few get punishment for what they have never done, such as being a city prisoner on charges of murdering other person and whether they actually did it or maybe the people are in a situation of bad destiny that may cause injustice. Therefore, destiny can determine whether a person's life journey is happy or not.

\section{References}

Amantio, Ser. di.Nicolao. (2018). William Landay. Retrieved from https://en.m.wikipedia.org/wiki/ William_Landay on February 2019.

Cahn, N Edmond. (1975). The sense of injustice. pp 24-26, 106. ISBN 0253200555. Blomington Indiana: Indiana University Press

Creswell, J. W. (2009). Research Design. Canberra: Golden Publishing Company.

Creswell, J. W. (2013). Qualitative Inquiry and Research Design Choosing Among Five Approaches. United states of Amerika : SAGE

Fowler, A, Lastair. (1987). A History of Literature. London: Basil Blackwell Ltd

Gullen, Fethullah. (2015). Makna Takdir Menurut Bahasa dan Istilah Retrieved from https://fgulen.com/id/karya-karya/qadar/49460-makna-takdir-menurut bahasa dan-istilah on February 2019.

Haderi, Anang. (2014). "Takdir dan Kebebasan Menurut Fethullah Gulen”. In Teologia, Vol.25 No.2. Kalimantan Tengah: Forum Studi Islam dan Sosial (FoSIS) 
Harcourt, H. M. (2013). The American Heritage Dictionary. America:Houghton Mifllin Harcourt Publishing Company

Hayeks, Von. (1978). "The Quest For Justice". In The mirage of social justice. Vol.2. ISBN 9780226320830 Illinois, United States : University of Chicago Press

Hull, Jim. (2013). The True Definition Of a Protagonist. Retrieved from http:// narrativefirst.com/articles/the-true-definition-of-a-protagonist on June 2019.

Hidayati. (2019). Anguish in Alexander Dumas' Novel "The Count of Monte Cristo". Language Literacy: Journal of Linguistics, Literature and Language Teaching. Retrieved from https://jurnal.uisu.ac.id/index.php/languageliteracy/article/view/1994/pdf_1 on 12 April 2019.

Ismail, Sulaiman, dan Saharani. (2011) Pengantar Ilmu Komunikasi. Langsa: STAIN Zawiyah Cot Kala Langsa

King Martin Luther, Jr., (1963). Letter from a Birmingham Jail Retrieved from https://www.theatlantic.com/magazine/archive/2018/02/letter-from-birminghamjail/552461/ on 20 June 2019.

Landay, William. (2012). Defending Jacob. United States Of America:Bantam books

Moore Barrington, Jr. (1978). Injustice: The Social Bases of Obedience and Revolt. Palgrave Macmillan. pp. passim. ISBN 0333247833. New York: Routledge

Shklar, N Judith N. (1992). "passim, see esp Chpt 1, 'Giving Injustice its due'". The Faces of Injustice. ISBN 0253200555. New Haven Amerika Serikat: Yale University Press

Schielke, Samuli. (2018). Destiny as a relationship.HAU: Journal of Ethnographic Theory 8 (1/2): 343-346. DOI: $10.1086 / 698268$

Thomas, W. Simon. (1995). "passim, see esp Chpt 1, 'Injustice versus Justice'". Democracy and Social Justice.ISBN 0847679381. Lanham Maryland: Rowman \& Littlefield

Wolgast Elizabeth. (1987). The Grammar of Justice. p. 103. ISBN 0801494028. Ithaca, New York: Cornell University Press

Weil Simone, The Way of Justice as Compassion. Rowman \& Littlefield. ISBN 9780847690800 New Jersey : Princeton Theological Seminary

Wiley, John. (2010). Webster's New Worl College Dictionary. Ohio: Wiley Publishing, Inc.

(2019). Bryan William Jennings. Retrieved from https://www.passiton.com/inspirational-quotes/7201-destiny-is-no-matter-ofchance-it-is-a-matter on 11 April 2019

. (2019). Injustice. Retrieved from https://en.wikipedia.org/wiki/Injustice on January 2019.

. (2019). Novel. Retrieved from https://id.wikipedia.org/wiki/Novel on February 2019. 